\title{
Optogenetics for Understanding and Treating Brain Injury: Advances in the Field and Future Prospects
}

\author{
Yuwen Sun ${ }^{1,+}$, Manrui Li ${ }^{2,+}$, Shuqiang Cao ${ }^{2}$, Yang Xu ${ }^{1}$, Peiyan $\mathrm{Wu}^{1}$, Shuting Xu ${ }^{1}$, Qian Pan ${ }^{1}$, Yadong Guo ${ }^{3}$, \\ Yi Ye ${ }^{4}$, Zheng Wang ${ }^{5}$, Hao Dai ${ }^{6}$, Xiaoqi Xie ${ }^{7}$, Xiameng Chen ${ }^{6, *(D)}$ and Weibo Liang ${ }^{2, *(D)}$
}

1 West China School of Basic Medical Sciences and Forensic Medicine, Sichuan University, Chengdu 610041, China; 2017151611001@stu.scu.edu.cn (Y.S.); 19944501946a@gmail.com (Y.X.); mdsxwu2002@163.com (P.W.); 2021151610079@stu.scu.edu.cn (S.X.); panqian1078@scu.edu.cn (Q.P.)

2 Department of Forensic Genetics, West China School of Basic Medical Sciences and Forensic Medicine, Sichuan University, Chengdu 610041, China; marylee078@gmail.com (M.L.); caoshuqiang916@163.com (S.C.)

3 Department of Forensic Science, School of Basic Medical Sciences, Central South University, Changsha 410013, China; gyd82@126.com

4 Department of Forensic Toxicological Analysis, West China School of Basic Medical Sciences \& Forensic Medicine, Sichuan University, Chengdu 610041, China; yeyiconan@163.com

5 Institute of Forensic Medicine, West China School of Basic Science and Forensic Medicine, Sichuan University, Chengdu 610041, China; wangzhengtim@scu.edu.cn

6 Department of Forensic Pathology and Forensic Clinical Medicine, West China School of Basic Medical Sciences and Forensic Medicine, Sichuan University, Chengdu 610041, China; daihao22@gmail.com

7 Department of West China Clinical Medicine, Sichuan University, Chengdu 610041, China; xiaoqixie1898060@163.com

* Correspondence: xmchen990@gmail.com (X.C.); liangweibo@scu.edu.cn or liangweibo@gmail.com (W.L.)

+ These authors contributed equally to this work.

\section{updates}

Citation: Sun, Y.; Li, M.; Cao, S.; Xu, Y.; Wu, P.; Xu, S.; Pan, Q.; Guo, Y.; Ye, Y.; Wang, Z.; et al. Optogenetics for Understanding and Treating Brain Injury: Advances in the Field and Future Prospects. Int. J. Mol. Sci. 2022, 23, 1800. https://doi.org/ $10.3390 /$ ijms 23031800

Academic Editors: Mootaz Salman, Philip Kitchen, Roslyn Bill and Firas Kobeissy

Received: 27 December 2021

Accepted: 3 February 2022

Published: 4 February 2022

Publisher's Note: MDPI stays neutral with regard to jurisdictional claims in published maps and institutional affiliations.

Copyright: (c) 2022 by the authors. Licensee MDPI, Basel, Switzerland. This article is an open access article distributed under the terms and conditions of the Creative Commons Attribution (CC BY) license (https:// creativecommons.org/licenses/by/ $4.0 /)$.

\begin{abstract}
Optogenetics is emerging as an ideal method for controlling cellular activity. It overcomes some notable shortcomings of conventional methods in the elucidation of neural circuits, promotion of neuroregeneration, prevention of cell death and treatment of neurological disorders, although it is not without its own limitations. In this review, we narratively review the latest research on the improvement and existing challenges of optogenetics, with a particular focus on the field of brain injury, aiming at advancing optogenetics in the study of brain injury and collating the issues that remain. Finally, we review the most current examples of research, applying photostimulation in clinical treatment, and we explore the future prospects of these technologies.
\end{abstract}

Keywords: opsins; traumatic brain injury; neural circuitry; neuronal apoptosis; neuroregeneration

\section{Introduction}

Optogenetics is a novel technique that incorporates the knowledge of bioengineering, genetics, optics, virology, and neuroscience [1]. Optogenetics combines genetic manipulation with optical stimulation, making target cells obtain or lose specific functions in vivo [2]. The applications and achievements of optogenetics benefit from the development of its core technologies, such as the discovery of additional microbial opsin variants, development of opsin targeting strategies, and advancement of optical targeting devices. Further, the integration of auxiliary technologies, such as data visualization using electrophysiology and neuron activity imaging, gives optogenetics the marked advantage of reflecting cellular function on different temporal and spatial scales [1]. The combinations of these technologies are powerful tools for analyzing the abnormalities of neural circuits in brain diseases, such as Parkinson's disease [3], epilepsy [4], pain [5], etc., thereby promoting their understanding and treatment. Further development of these technologies will likely contribute to revolutions in neuroscience research.

To date, numerous studies have focused on elucidating complex neural processes and treating neuropsychiatric diseases [6-8], but few studies have systematically reviewed the 
latest studies to examine the potential use of optogenetics to map and treat brain injury. Brain injury places a significant health burden on individuals and communities [9-13]. After a primary injury is caused by bleeding, vascular occlusion, or mechanical forces, secondary alterations such as consequent axonal shearing, blood-brain barrier (BBB) disruption, etc., may lead to aggravated neuronal dysfunction and cell death [14,15], amplifying the negative outcomes of acute brain injury (ABI). Owing to the complicated pathophysiology and various clinical characteristics of brain injury, post-acute treatment options are limited. Numerous potential treatment methods have been explored in multiple animal models, including transcranial magnetic stimulation, electrical cortical stimulation, deep brain stimulation, pharmacological approaches [16,17], etc. However, few studies have provided evidence of therapeutic potential in human trials. Limitations of these treatments include that stimulation therapies may provide temporal control of neurons but often lack spatial specificity, pharmacological therapies exhibit spatial specificity but lack precise temporal control, etc.

Lately, researchers are incorporating single-cell control and millisecond precision timing into the development of treatment options using optogenetics. Optogenetics is superior to conventional methods in some respects because of more precise spatiotemporal control of cellular processes and the option of performing parallel investigations at multiple sites. Although optogenetics provides solutions to notable challenges associated with conventional neuroscience research, these methodologies still have some shortcomings that need to be innovatively addressed to enhance their future application potential [18]. This review aims to provide an overview of the latest research in the field of brain injury mapping and therapeutics using optogenetics and to summarize future development strategies that will enhance its prospects as a tool for understanding pathological conditions associated with brain injury.

\section{Fundamentals of Optogenetics}

The application and development of optogenetics allows neuroscientists to control neuronal activities with light and permits multi-level neuroscience research. To this end, the expression of light-sensitive proteins and light-mediated modulation of cellular function is critical.

\subsection{Overviews of Opsins}

Optogenetics utilizes the light-sensitive proteins (e.g., opsins) to regulate the activities of target cell populations using light stimulation. Table 1 summarizes several common optogenetic tools with distinctive characteristics. Microbial (type I) and animal (type II) opsins were long considered to be the only existing types of rhodopsins; however, a recently discovered protein family with an inverted membrane topology - the heliorhodopsin-is expected to be incorporated as a new optogenetic tool in future research $[19,20]$.

Lately, there have been increasing concerns that currently available optogenetic tools may have low efficiency issues and off-target effects. The weak current and rapid inactivation properties of natural channelrhodopsins (ChRs) limited their clinical application. To circumvent this issue, attempts have been made to improve channel dynamics and operational light selectivity of opsins to compensate for above limitations [26,31]. One method of improving light sensitivity is opsin modification using genetic engineering, examples of which include iC1C2 (chimeras of ChR1 and ChR2) [32] and SOUL (an engineered step function opsin containing a particular combination of mutations) [33]. Another method is to search for opsins from other species or optimize existing $\mathrm{ChR}$ variants. Examples include the viral rhodopsins OLPVR1, VirChR1 [34] and Chloromonas oogama ChR [35].

Bidirectional control of neuronal activity was needed in some studies but has been challenging until last year [36]. In 2021, Vierock et al. [37] reported that a two-channel fusion protein-BiPOLES (Bidirectional Pair of Opsins for Light-induced Excitation and Silencing) - induces neuronal excitation with red light and inhibition with blue light. Until now, the BiPOLES has been utilized and verified in several animal models [37]. 
Table 1. Commonly Used Optogenetic Tools.

\begin{tabular}{|c|c|c|c|c|}
\hline Opsins & Description & Mode & Properties & Reference \\
\hline ChR2 & $\begin{array}{c}\text { Cation channel responsive to blue } \\
\text { light; commonly used for } \\
\text { optogenetics }\end{array}$ & Excitatory & $\begin{array}{l}\text { Millisecond temporal } \\
\text { precision; a high risk of } \\
\text { desensitization }\end{array}$ & Boyden et al., 2005 [21] \\
\hline ChETA, ChIEF & $\begin{array}{l}\text { Ultrafast opsin, site directed } \\
\text { mutation and Chimeric } \\
\text { modification of ChR2 }\end{array}$ & Excitatory & $\begin{array}{c}\text { Higher frequency } \\
\text { activation and more rapid } \\
\text { deactivation than ChR2 }\end{array}$ & $\begin{array}{c}\text { Lin et al., } 2009 \text { [22] } \\
\text { Gunaydin et al., } 2010 \text { [23] }\end{array}$ \\
\hline VChR1 & $\begin{array}{l}\text { Redshifted opsin with a similar } \\
\text { photocurrent as ChR1 }\end{array}$ & Excitatory & $\begin{array}{l}\text { Slow photocurrent kinetics; } \\
\text { low efficiency in high } \\
\text { frequency stimulations }\end{array}$ & Zhang et al., 2008 [24] \\
\hline C1V1 & $\begin{array}{l}\text { A chimeric combination of ChR1 } \\
\text { and VChR2 }\end{array}$ & Excitatory & $\begin{array}{l}\text { High light sensitivity; good } \\
\text { expression level on } \\
\text { membranes }\end{array}$ & Hososhima et al., 2015 [25] \\
\hline ReaChR & Mutant based on VChR1 & Excitatory & $\begin{array}{l}\text { Better opsin expression } \\
\text { than VChR1; slow channel } \\
\text { closing rate }\end{array}$ & Lin et al., 2013 [26] \\
\hline $\mathrm{NpHR}$ & $\begin{array}{c}\text { Chloride channel responsive to } \\
\text { yellow light }\end{array}$ & Inhibitory & $\begin{array}{l}\text { Millisecond temporal } \\
\text { precision; poor trafficking } \\
\text { to the membrane; unsuited } \\
\text { for long-scale or } \\
\text { high-quantity silencing }\end{array}$ & Nagel et al., 2003 [27] \\
\hline eNpHR & $\begin{array}{c}\text { Site directed mutation and } \\
\text { chimeric modification of } \mathrm{NpHR}\end{array}$ & Inhibitory & $\begin{array}{l}\text { High-level expression with } \\
\text { augmented inhibitory } \\
\text { function; better opsin } \\
\text { expression than NpHR; } \\
\text { interfere with excitability } \\
\text { of neurons }\end{array}$ & $\begin{array}{l}\text { Gradinaru etal., } 2008 \text { [28] } \\
\text { Ferenczi et al., } 2012 \text { [29] }\end{array}$ \\
\hline Arch & $\begin{array}{l}\text { Proton pump silences neurons in } \\
\text { response to yellow light }\end{array}$ & Inhibitory & $\begin{array}{l}\text { Good for large-scale } \\
\text { silencing; high light } \\
\text { sensitivity, photocurrents } \\
\text { and expression levels }\end{array}$ & Chow et al., 2010 [30] \\
\hline
\end{tabular}

ChR2 denotes Channelrhodopsin-2, ChETA Channelrhodopsin-2 with E123T mutation, VChR1 Volvox carteri channelrhodopsin-1, ReaChR Red-activatable channelrhodopsin, NpHR Halorhodopsins, eNpHR enhanced NpHR, Arch Archaerhodopsin.

Except for opsins, non-opsin-based photosensory proteins has been emerging to control protein activity and increasingly meet certain experimental requirements [38-40]. In recent studies, fluorescein, a strongly bioluminescent protein, allows reliable activation of neural circuits at different temporal-spatial resolutions and regulation of neurons with satisfactory experimental outcomes [41,42]. Therefore, the research for new unique photoproteins alternatives as well as the assessment and optimization of existing opsin properties is valuable. In so doing, new opportunities for designing efficient internal light-inducing systems are introduced, and their clinical applications may be facilitated.

\subsection{Light Delivery Systems}

Light stimulation, targeting specific opsins, acts as an essential component of optogenetics. A laser or light-emitting diode (LED) can be coupled with conventional one-photon (1P) or two-photon (2P) imaging to observe neural activities and subsequent behavioral changes. Regardless of the method used, light scattering limits the depth of light penetration and affects 1P and 2P imaging. Furthermore, external light sources (laser or LED) can cause unexpected light-induced behaviors, such as fear responses and disruptive movement, which may affect the experimental outcomes in behavioral research. To avoid these behaviors and achieve deep-brain photostimulation, the use of invasive optical fibers may be necessary. However, such approaches pose the risk of greater or unintended damage to the brain tissue.

Classical optical fibers are planar fibers, which limit light penetration in a small region [43]. Tapered fibers allow for input angle of cylindrical light to be adjusted so that the 
same fiber can illuminate two different brain regions [44]. To improve the spatial accuracy, microscale LED arrays and tapered optical fibers, which reduce injury and imprecise positioning of the light sources, have been widely applied this year [44,45]. In addition, the development of nanomaterials has become a research objective for optogenetics. Nanomaterials are often used to minimize photothermal effect while optimizing light induction. As efficient light absorbers, gold-based nanomaterials have been placed near the targeted tissue, thereby avoiding thermal damage to non-targeted areas [46]. Carbon nanotubes, a stretchable transparent electrode array combining nanotechnology and optogenetics, have been used to record response signals from cortical surfaces after photostimulation. These nanotubes may potentially be used for in-depth, real-time, and continuous monitoring of disrupted cerebral cortex function [47]. Upconversion nanoparticles absorb tissue-penetrating, near-infrared light and emit wavelength-specific visible light. These characteristics allowed their use for neural stimulation in several animal models [48,49], and indicated their potential to be a substitute for invasive optical fibers [50].

Although recent efforts have greatly improved existing optogenetic devices, their potential clinical applications in human patients will require further development and careful consideration. Continuous advancements in the fields of materials science, nanotechnology, chemistry, and optics are needed for the possible application of fibreless optogenetics in neuroscience and beyond.

\section{Optogenetics Applied to Brain Injury}

In the field of brain injury research, optogenetics has been preliminarily used to induce and monitor traumatic brain injury (TBI) in animal models (Table 2). In this section, we focus on the contribution of optogenetics to the field of brain injury in recent years, including TBI, stroke, and spinal cord injury (SCI). In addition, we discuss prospects for the practical application of optogenetics for these injuries.

Table 2. Optogenetic TBI studies.

\begin{tabular}{|c|c|c|c|c|}
\hline Research Topics & Model & Optogenetic Tools & Area & Reference \\
\hline $\begin{array}{l}\text { Microglia-mediated mechanisms } \\
\text { underlying synaptic loss }\end{array}$ & Controlled cortical impact & Parvalbumin & $\begin{array}{c}\text { CA1 } \\
\text { hippocampus }\end{array}$ & Krukowski et al., 2021 [51] \\
\hline $\begin{array}{l}\text { Longitudinal changes in cortical } \\
\text { motor map }\end{array}$ & Controlled cortical impact & ChR2 & Motor cortex & Nguyen et al., 2021 [52] \\
\hline $\begin{array}{l}\text { Improvement of spatial } \\
\text { recognition memory impairment }\end{array}$ & Controlled cortical impact & $\mathrm{ArCh}$ & RSC & Zeng et al., 2020 [53] \\
\hline $\begin{array}{l}\text { Response signals from cortical } \\
\text { surfaces }\end{array}$ & Controlled cortical impact & ChR2 & RSC & Zhang et al., 2018 [47] \\
\hline $\begin{array}{l}\text { Relationship between neuronal } \\
\text { and vascular reactivity }\end{array}$ & Closed head injury & ChR2 & $\begin{array}{l}\text { Cortex, arterioles } \\
\text { and venules in } \\
\text { brain }\end{array}$ & Mester et al., 2021 [54] \\
\hline Neuronal function following TBI & Closed head injury & ChR2 & $\begin{array}{l}\text { Peri-contusional } \\
\text { brain tissue }\end{array}$ & Adams et al., 2018 [55] \\
\hline $\begin{array}{l}\text { The structural reorganization of } \\
\text { axonal projection terminals and } \\
\text { the functional activity of the } \\
\text { thalamocortical network }\end{array}$ & Fluid percussion injury & ChR2 & 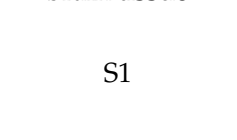 & Ndode-Ekane et al., 2021 [56] \\
\hline $\begin{array}{c}\text { Survival and maturation of } \\
\text { newborn neurons during adult } \\
\text { neurogenesis }\end{array}$ & Fluid percussion injury & ChR2 & DG hippocampus & Zhao et al., 2018 [57] \\
\hline
\end{tabular}

CA1 hippocampus denotes Cornu Ammonis subfield 1 in hippocampus, RSC Retrosplenial Cortex, S1 Primary somatosensory cortex, DG hippocampus Dentate gyrus in hippocampus.

\subsection{Optogenetics in Brain Monitoring}

A combination of clinical assessment and imaging is commonly used to judge the severity and prognosis of brain injury [58]. Additional approaches can help identify local environmental insults. These approaches include cerebral microdialysis, cerebrovascular pressure response and pressure reactivity indices, intracranial and cerebral perfusion pressure monitoring, and identification of serum markers for neuronal damage [59-62]. 
These approaches are also valuable for predicting prognosis, measuring the degree of injury, and guiding intervention methods.

Optogenetics is another approach with brain-monitoring potential in cases of brain injury, which facilitates the study of pathological processes post-injury and therapeutic targets at a different level. Using optogenetic methods, the dynamic tracking of secondary changes after brain injuries are possible, offering an added advantage over current brain monitoring methods. Many experimental models in which this approach has been applied emphasize the utility of optically recording neural activity $[63,64]$.

Optogenetics involves optically recording changes in membrane potential and observing neuronal signal transmission [65]. Therefore, functional brain research can be facilitated using this technique. Drawing inspiration from previous studies, Adams and colleagues [55] first employed optogenetic photostimulation to monitor and explicate neuronal function following TBI. They stimulated cortical pyramidal neurons in a mouse model of repeated mild TBI (mTBI) and investigated neuronal function change through bilateral intracranial electrophysiological recordings. Their experimental data suggested that optical stimulation led to reduced evoked neuronal responses and impaired functioning of the surviving neurons [55]. Another novel approach-in vivo optogenetic motor mapping, was first reported by Nguyen et al. [52]. In their study, this optogenetic method was used to evaluate longitudinal changes in cortical motor maps in an mTBI model, remedying the limitation of some conventional research techniques. Real-time performance is another advantage of optogenetics. Lately, studies successfully monitored real-time neurotransmitter release and synapse formation using optogenetics [66,67], which has been a challenge previously.

Regional abnormalities in cerebral blood flow are important to understanding the pathogenesis of brain injuries as well as monitoring the clinical course. Adams et al. has demonstrated that photostimulation of $\mathrm{ChR} 2$ can be used to probe neurovascular unit function with more robust vascular responses and greater spatiotemporal control than physiological stimuli [55]. After inducing ChR2 expressing in mice, Mester et al. [54] measured cerebral vessel activity and local neuronal reactivity after mTBI and found that photostimulation resulted in dilatation and augmented venular reactivity. This was the first study to integrate optogenetics, $2 \mathrm{P}$ fluorescence microscopy, and intracortical electrophysiological recordings for the examination of neurovascular unit dysfunction after repeated mild TBI [54]. Taken together, recent studies suggest that optogenetic techniques can complement current methods of brain monitoring and are potential tools for brain injury treatment and analysis.

\subsection{Optogenetics in Analyzing Neural Circuitry}

Neural circuits are composed of highly interconnected neurons with distinct functions which coordinate simultaneously to drive the normal operation of the nervous system. Owing to the disconnection of surviving circuits after brain injury, patients may suffer sensory or motor impairments, and the detection of functional abnormalities in specific neuronal nuclei and neural circuits might aid in the prevention, diagnosis, and treatment of these disorders. The high temporospatial resolution feature of optogenetics makes it particularly suitable for neuronal circuit manipulation, which benefits the study of neuronal clusters from multiple dimensions, the changes in abnormal neural circuits and the pathogenesis of certain diseases, such as Alzheimer's disease [68], Parkinson's disease [69], and Huntington's disease [70].

Cheng et. al. report that optically targeting specific cerebral cortex regions [71] (ipsilesional primary motor cortex, iM1) and nuclei [72] (lateral cerebellar nucleus, LCN) leads to a significantly increased capacity for neuroplasticity, with elevated expression of the plasticity marker, axonal growth-associated protein 43 (GAP43). A comparison between LCN stimulation and iM1 stimulation suggests that photostimulation of the LCN may be more efficient in increasing GAP43 in the ipsilesional somatosensory cortex [72]. A recent study also showed that optogenetic stimulation of the LCN produced functional benefits in a murine stroke model and downregulated the expression of neuronal nitric oxide synthase, 
a key regulator of the neurovascular response in stroke, suggesting that optogenetic stimulation of the LCN holds promise for facilitating functional limb movements and behavioral recovery [73].

The optogenetic monitoring and optimization of axon connections has emerged as an advanced tool in the field of neuronal circuit study [66]. After introducing viral vectors carrying the fluorescently-tagged opsin ChR2 transgene into TBI rats, Ndode-Ekane et al. [56] observed the reformulation of axonal projection terminals in the primary somatosensory cortex. Optogenetic photostimulation led to reduced density of axonal terminals in the cortex and hyperexcitability of thalamo-cortical network activity after TBI [56]. Similarly, another study revealed that renewed cortico-spinal tract axons can be integrated into the inferior neural circuit through optogenetics, and that the regenerated axons promoted the recovery of sensorimotor function [74]. Combined with other imaging methods, this lightsensitive technology can promote the reorganization and functional recovery of impaired neural circuits. Using in vivo calcium imaging, Tennant et al. [75] found that stroke results in disruption of axonal synaptic connections in the damaged cortex and causes sustained excitability impairment of surviving thalamocortical circuits. Further, they revealed that repeated photostimulation in the transcranial optical window accelerated the reorganization of thalamocortical synaptic boutons and the subsequent recovery of cortical circuit function for the first time [75].

Optogenetic photostimulation can be used to investigate the role of pathological processes and functional recovery post injury by targeting neuronal circuits. Memory and cognitive impairments caused by brain injury may have serious effects on survivors, and functional alterations in neural circuits are of the leading factors contributing to these impairments. To explore the relationship between impaired spatial recognition memory function and corresponding brain regions, Zeng et al. [53] optogenetically inhibited the function of the retrosplenial cortex (RSC) and observed memory impairment in wildtype mice. Currently, light stimulation alone cannot restore all brain functionality after injury, whereas the combination of optogenetics and other type of treatment may promote recovery to a greater extent. For example, optogenetic stimulation of the motor cortex combined with exercise training has been shown to facilitate neuroplasticity and restore motor function [76]. Considering the evidence, optogenetics allows for the electrical activity of individual neurons to be observed and the function of essential neural circuits to be analyzed by activating or inhibiting sites via photostimulation.

\subsection{Optogenetics in Protecting Neural Cells}

Accumulated evidence from animal and human studies demonstrates that apoptosis, autophagy, acidosis, etc., contribute to the overall pathologenesis following brain injury [77-79], interventions targeting these factors also show marked prospects for brain injury treatment. In 2020, Bo et al. [80] transferred protons out of penumbra neurons and explored whether the proton-transfer could mitigate tissue acidification and induce neuroprotection after focal cerebral ischemia in rats. In this study, the penumbral neurons were regulated by an optical-driven pump (archaerhodopsin/ArchT group) or channel (rhodopsin-2/ChR2 group). Neutral red fluorescence imaging was used to monitor the intracellular $\mathrm{pH}$ after ischemia, and the overall cerebral blood flow response was measured to evaluate neurological function. Their findings demonstrated that intracellular acidosis was mitigated by the optogenetic translocation of protons out of ArchT-expressing penumbral neurons $30 \mathrm{~min}$ after an ischemia event, showing therapeutic potential. Lately, another study further supports the potential neuroprotective effect of optogenetic technology following ischemic penumbra [81]. Using human induced pluripotent stem cells, researchers examined the electrophysiological activity of neuronal networks under controlled hypoxic conditions and found a decrease of their activity and synchronicity under low oxygen conditions. Photostimulation exhibited neuroprotective effects on neurons suffering hypoxia by maintaining or triggering the lactate shuttle through activating signaling molecules. In addition, photostimulation induced secretion of various factors and changes in neuronal 
cell activity, which also affected the outcomes of brain injury. For example, when the hippocampus of a rat carrying ChR2 was optically stimulated, the expression of Bcl-xL, an antiapoptotic protein, was upregulated in the neurons and surrounding cells [82].

Aside from neurons, autophagy and acidosis are also activated in various cell types after stroke, such as glial cells and microvascular cells. Optogenetics is known to impart cell type-specific control of glial cell activity with high spatiotemporal resolution. Therefore, Beppu et al. [83] attempted to reverse glial acidosis in hypoperfused tissue by activating ArchT and driving the outward proton pump using optical stimulation. In response, the release of glutamate was inhibited, and ischemic brain injury was alleviated in vivo, offering another approach that can potentially be used for neuroprotection.

In conclusion, these results show that optogenetic interventions targeting the acidbase balance and inhibiting nerve cell apoptosis can improve the survival ability of tissues balance, apoptosis or autophagy of neural cells are prospective for the treatment of brain injury.

\subsection{Optogenetics in Promoting Regeneration}

Brain injury may induce permanent neuron loss. Given the limited number of endogenous neural stem cells (NSCs), inducing regeneration in a damaged nervous system is challenging. However, neural transplantation (i.e., supplementing the injured brain with exogenous stem cells) may be a feasible approach. Transplanted stem cells achieve neuroprotection, immune regulation, and neuroregeneration through multiple mechanisms [84-86]. Optogenetic techniques combined with NSC-based therapies have the potential to enhance neuroregeneration and improve cell therapy outcomes [87].

Recent research has demonstrated that photostimulation of host cortico-spinal tract axons being regenerated into grafts elicited distinct and segregated neuronal network responses [86]. Optogenetic stimulation of graft-derived axons extending from the graft into the denervated spinal cord also triggered local host neuronal network responses, and behavioral stimulation elicited focal synaptic responses within grafts as shown by in vivo imaging [86]. In another study, optogenetic stimulation intact rat corticospinal tract post-stroke restores motor control by promoting axonal sprouting from the intact to the denervated cervical hemi-cord [88]. In addition, optogenetics has been used to drive the excitatory outputs of grafted NSCs and to increase forelimb use as well as motor activity on the stroke-affected side in a rat model [89].

In neural cell regeneration, recent work by Giraldo et al. [90] also indicated the marked potential of optogenetics in treating conditions such as SCI. In this study, blue light stimulation of NPCs engineered to ectopically express ChR2 (ChR2-NPCs) prompted an influx of cations and a subsequent increase in proliferation and differentiation from NPCs into oligodendrocytes and neurons. Further, stimulation drove the polarization of astrocytes from a pro-inflammatory to a pro-regenerative/anti-inflammatory phenotype. In another study, researchers used optogenetic techniques to control the activity of striatal neurons and investigated how their activity affected the survival and migration of transplanted NSCs as well as the overall neurological outcome after ischemic stroke [91]. They found that inhibitory stimulation of striatal neurons at 3-7 days post- ischemia led to increased neuroregeneration in the subventricular zone, bridging the gap between neuronal modulation and behavior of the NSCs [91]. While studies have been conducted to demonstrate the combined effect of stem cell-based therapy and optogenetics in stroke and SCI models, few have examined their effect in a TBI model. To the best of our knowledge, there has been only one study involving stem cell-based therapy with optogenetics in TBI [57]. In this study, the doublecortin, which is expressed by neuronal progenitor and postmitotic neuronal precursor cells, was coupled with ChR2-EGFP. Results showed that this ChR2-mediated depolarization approach promoted survival and maturation of newborn cells after TBI.

Combinatorial approaches using optogenetics with other advanced methods have also exhibited therapeutic promise. Hydrogel technology is currently used to study spinal cord repair and neuroregeneration [92,93]. Combined with light stimulation, injectable self- 
healing hydrogels provided shear forces that enhance the efficiency of a plasmid encoding bacteriorhodopsin, thus enabling the introduced NSCs to proliferate and differentiate smoothly [94].

\section{Clinical Perspectives and Challenges}

Currently, either conventional stimulation techniques or pharmacological therapies have some limitations in their clinical application. Optogenetic real-time monitoring and therapeutic interventions may be optimized for choice or provide a complementary treatment for the intervention of brain injury.

Optogenetics holds great promise for therapeutic application in clinics. Until now, an important achievement in optogenetic therapy was obtained in treating human retinitis pigmentosa- a neurodegenerative eye disease [95]. A serotype $2.7 \mathrm{~m} 8$ adeno-associated virus (AAV) vector, encoding the light-sensing channelrhodopsin protein ChrimsonR fused with the red fluorescent protein tdTomato13, was administered by a single intravitreal injection into the patient's worse-seeing eye to target retinal ganglion cells. Specially engineered goggles and a neuromorphic camera then converted images into light pulses that were projected onto the patient's retina to activate modified retinal ganglion cells for visual tasks. Results showed that the previously blind patient could identify, count, locate and touch different objects with his post-treatment eyes when wearing the light-stimulating goggles [95]. In addition, prior research has reported that optogenetic stimulation could be applied in many other fields, including respiratory [96], muscle [97], and urinary systems [98]. All these results demonstrated the great value of the optogenetics in treating human disease or injury.

Despite broad clinical application prospects, there remain some important challenges associated with optogenetics-based therapies. 1 . The main hindrance is the delivery of optogenetic tools in patient's brain. This invasive operation may induce damage to brain tissue. In addition, weight/size of the implants and power cable connections, which may affect patients' normal activities, also need to be considered. Recent advances in wireless technology and device miniaturization might partly solve this issue [99], while clinical application is still some way off. 2. Safety issue of the virus. Virus transduction is a widely used and effective method in optogenetic stimulation. The AAV is regarded as an ideal viral vector applied in gene therapy for many diseases [100-102]. However, a recent trial of AAV vector therapy has shown its possibility of inducing cancer [103]. The safety issue of gene therapy has once again been thrust into the public eye and needs to be carefully addressed. 3. Research on non-human primates (NHP) is still in its infancy. Compared to rodents, NHPs have larger brain volume and a more complicated central nervous system, all of which present great challenges for the translation of optogenetic study into a clinically effective therapy [104]. 4. As foreign antigens, opsins or viruses produce an underlying immune response, which may lead to neuronal death [105]. 5. Numerous ethical issues related to the application of optogenetics in humans, also need to be accounted for [106].

\section{Conclusions}

With high spatiotemporal precision, optogenetics has paved the way for its multiple applications in the neuroscience research and related translational medicine. In this review, we summarized the status quo of optogenetics and its application in the most recent brain injury research, including monitoring the brain, analyzing neural circuitry, protecting neural cells and promoting regeneration. Further, we reviewed the therapeutic potential and current challenges of this approach, aiming at advancing optogenetics in understanding and treating pathological conditions related to brain injury.

Author Contributions: Y.S. and M.L. searched and reviewed literature, drafted manuscript and revision; S.C., Y.X., P.W., S.X., Q.P., Y.G., Y.Y., Z.W., H.D. and X.X. provided critical comments, discussed and revised the manuscript; X.C. and W.L. designed and formulated the review theme, viewed the literature, and finalized the manuscript. All authors have read and agreed to the published version of the manuscript. 
Funding: This work was supported by "the Fundamental Research Funds for the Central Universities" [grant number: 20826041E4142] from Sichuan University, and the "College Students' Innovative Entrepreneurial Training Plan Program" [grant number: 20220966L] from Sichuan University.

Institutional Review Board Statement: Not applicable.

Informed Consent Statement: Not applicable.

Data Availability Statement: Not applicable.

Conflicts of Interest: The authors declare no conflict of interest. The funders had no role in the design of the study; in the collection, analyses, or interpretation of data; in the writing of the manuscript, or in the decision to publish the results.

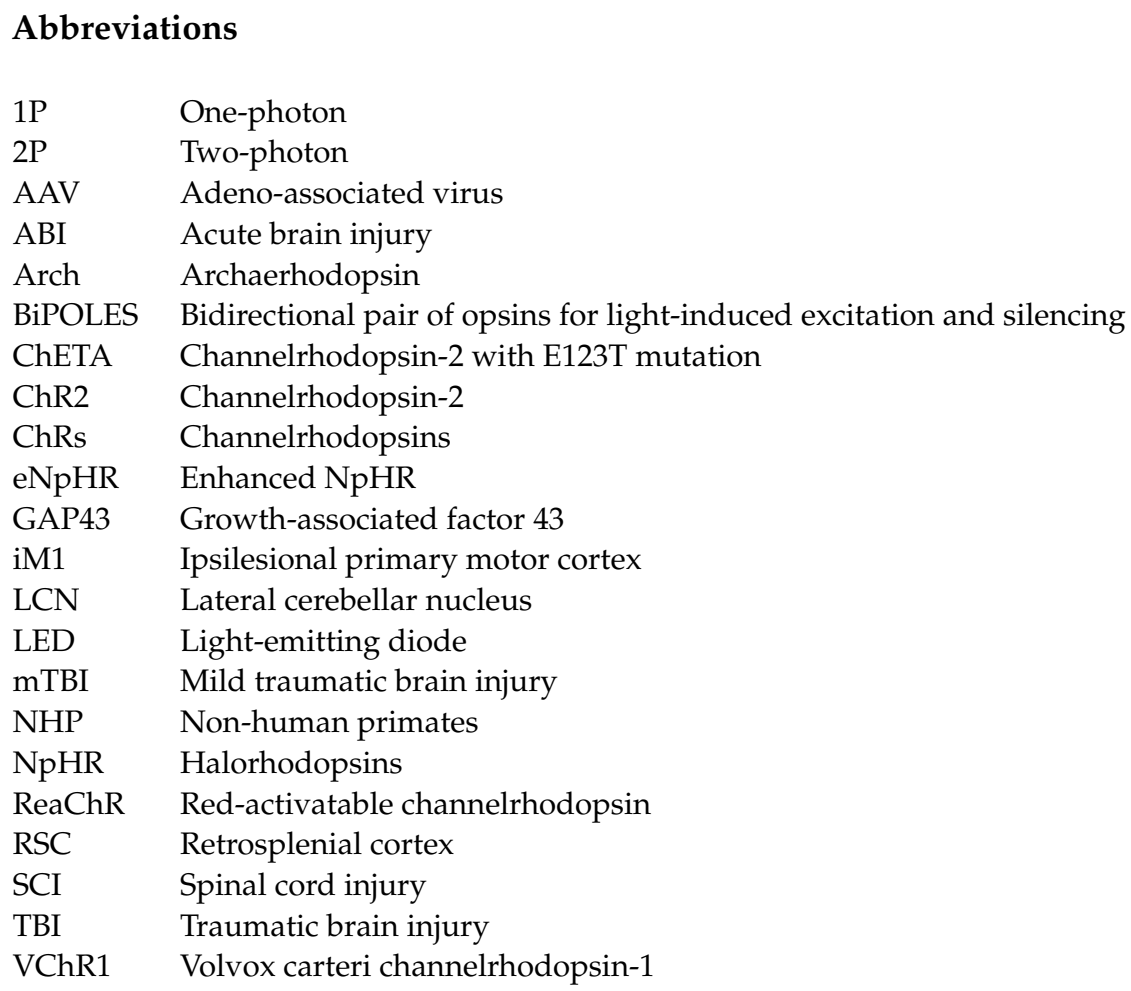

\section{References}

1. Kim, C.K.; Adhikari, A.; Deisseroth, K. Integration of optogenetics with complementary methodologies in systems neuroscience. Nat. Rev. Neurosci. 2017, 18, 222-235. [CrossRef] [PubMed]

2. Miesenböck, G. The Optogenetic Catechism. Science 2009, 326, 395-399. [CrossRef] [PubMed]

3. Magno, L.A.V.; Tenza-Ferrer, H.; Collodetti, M.; Aguiar, M.F.G.; Rodrigues, A.P.C.; da Silva, R.S.; Silva, J.D.P.; Nicolau, N.F.; Rosa, D.V.F.; Birbrair, A.; et al. Optogenetic Stimulation of the M2 Cortex Reverts Motor Dysfunction in a Mouse Model of Parkinson's Disease. J. Neurosci. 2019, 39, 3234-3248. [CrossRef] [PubMed]

4. Berglind, F.; Andersson, M.; Kokaia, M. Dynamic interaction of local and transhemispheric networks is necessary for progressive intensification of hippocampal seizures. Sci. Rep. 2018, 8, 5669. [CrossRef] [PubMed]

5. Liu, S.; Tang, Y.; Xing, Y.; Kramer, P.; Bellinger, L.; Tao, F. Potential Application of Optogenetic Stimulation in the Treatment of Pain and Migraine Headache: A Perspective from Animal Studies. Brain Sci. 2019, 9, 26. [CrossRef] [PubMed]

6. Donzis, E.J.; Estrada-Sánchez, A.M.; Indersmitten, T.; Oikonomou, K.; Tran, C.H.; Wang, C.; Latifi, S.; Golshani, P.; Cepeda, C.; Levine, M.S. Cortical Network Dynamics Is Altered in Mouse Models of Huntington's Disease. Cereb. Cortex 2020, 30, $2372-2388$. [CrossRef] [PubMed]

7. Zhang, X.Y.; Kim, J.; Tonegawa, S. Amygdala Reward Neurons Form and Store Fear Extinction Memory. Neuron 2020, 105, 1077-1093.e7. [CrossRef] [PubMed]

8. Huang, F.; Tang, B.; Jiang, H. Optogenetic investigation of neuropsychiatric diseases. Int. J. Neurosci. 2013, 123, 7-16. [CrossRef]

9. GBD 2016 Traumatic Brain Injury and Spinal Cord Injury Collaborators. Global, regional, and national burden of traumatic brain injury and spinal cord injury, 1990-2016: A systematic analysis for the Global Burden of Disease Study 2016. Lancet Neurol. 2019, 18, 56-87. [CrossRef] 
10. Joy, M.T.; Ben Assayag, E.; Shabashov-Stone, D.; Liraz-Zaltsman, S.; Mazzitelli, J.; Arenas, M.; Abduljawad, N.; Kliper, E.; Korczyn, A.D.; Thareja, N.S.; et al. CCR5 Is a Therapeutic Target for Recovery after Stroke and Traumatic Brain Injury. Cell 2019, 176, 1143-1157.e13. [CrossRef]

11. Hyder, A.A.; Wunderlich, C.A.; Puvanachandra, P.; Gururaj, G.; Kobusingye, O.C. The impact of traumatic brain injuries: A global perspective. NeuroRehabilitation 2007, 22, 341-353. [CrossRef]

12. Taylor, C.A.; Bell, J.M.; Breiding, M.J.; Xu, L. Traumatic Brain Injury-Related Emergency Department Visits, Hospitalizations, and Deaths-United States, 2007 and 2013. MMWR Surveill. Summ. 2017, 66, 1-16. [CrossRef]

13. Rajsic, S.; Gothe, H.; Borba, H.H.; Sroczynski, G.; Vujicic, J.; Toell, T.; Siebert, U. Economic burden of stroke: A systematic review on post-stroke care. Eur. J. Health Econ. 2019, 20, 107-134. [CrossRef]

14. Algattas, H.; Huang, J.H. Traumatic Brain Injury pathophysiology and treatments: Early, intermediate, and late phases post-injury. Int. J. Mol. Sci. 2013, 15, 309-341. [CrossRef]

15. Blennow, K.; Hardy, J.; Zetterberg, H. The neuropathology and neurobiology of traumatic brain injury. Neuron 2012, 76, 886-899. [CrossRef]

16. Yu, K.P.; Yoon, Y.S.; Lee, J.G.; Oh, J.S.; Lee, J.S.; Seog, T.; Lee, H.Y. Effects of Electric Cortical Stimulation (ECS) and Transcranial Direct Current Stimulation (tDCS) on Rats With a Traumatic Brain Injury. Ann. Rehabil. Med. 2018, 42, 502-513. [CrossRef]

17. Lu, H.; Kobilo, T.; Robertson, C.; Tong, S.; Celnik, P.; Pelled, G. Transcranial magnetic stimulation facilitates neurorehabilitation after pediatric traumatic brain injury. Sci. Rep. 2015, 5, 14769. [CrossRef]

18. Zare-Shahabadi, A.; Ataei, A.; Rezaei, N. Proteins brighten the brain. Life Sci. 2016, 167, 1-5. [CrossRef]

19. Pushkarev, A.; Inoue, K.; Larom, S.; Flores-Uribe, J.; Singh, M.; Konno, M.; Tomida, S.; Ito, S.; Nakamura, R.; Tsunoda, S.P.; et al. A distinct abundant group of microbial rhodopsins discovered using functional metagenomics. Nature 2018, 558, 595-599. [CrossRef]

20. Shihoya, W.; Inoue, K.; Singh, M.; Konno, M.; Hososhima, S.; Yamashita, K.; Ikeda, K.; Higuchi, A.; Izume, T.; Okazaki, S.; et al. Crystal structure of heliorhodopsin. Nature 2019, 574, 132-136. [CrossRef]

21. Boyden, E.S.; Zhang, F.; Bamberg, E.; Nagel, G.; Deisseroth, K. Millisecond-timescale, genetically targeted optical control of neural activity. Nat. Neurosci. 2005, 8, 1263-1268. [CrossRef] [PubMed]

22. Lin, J.Y.; Lin, M.Z.; Steinbach, P.; Tsien, R.Y. Characterization of engineered channelrhodopsin variants with improved properties and kinetics. Biophys. J. 2009, 96, 1803-1814. [CrossRef] [PubMed]

23. Gunaydin, L.A.; Yizhar, O.; Berndt, A.; Sohal, V.S.; Deisseroth, K.; Hegemann, P. Ultrafast optogenetic control. Nat. Neurosci. 2010, 13, 387-392. [CrossRef] [PubMed]

24. Zhang, F.; Prigge, M.; Beyrière, F.; Tsunoda, S.P.; Mattis, J.; Yizhar, O.; Hegemann, P.; Deisseroth, K. Red-shifted optogenetic excitation: A tool for fast neural control derived from Volvox carteri. Nat. Neurosci. 2008, 11, 631-633. [CrossRef] [PubMed]

25. Hososhima, S.; Yuasa, H.; Ishizuka, T.; Hoque, M.R.; Yamashita, T.; Yamanaka, A.; Sugano, E.; Tomita, H.; Yawo, H. Near-infrared (NIR) up-conversion optogenetics. Sci. Rep. 2015, 5, 16533. [CrossRef]

26. Lin, J.Y.; Knutsen, P.M.; Muller, A.; Kleinfeld, D.; Tsien, R.Y. ReaChR: A red-shifted variant of channelrhodopsin enables deep transcranial optogenetic excitation. Nat. Neurosci. 2013, 16, 1499-1508. [CrossRef]

27. Nagel, G.; Szellas, T.; Huhn, W.; Kateriya, S.; Adeishvili, N.; Berthold, P.; Ollig, D.; Hegemann, P.; Bamberg, E. Channelrhodopsin-2, a directly light-gated cation-selective membrane channel. Proc. Natl. Acad. Sci. USA 2003, 100, 13940-13945. [CrossRef]

28. Gradinaru, V.; Thompson, K.R.; Deisseroth, K. eNpHR: A Natronomonas halorhodopsin enhanced for optogenetic applications. Brain Cell Biol. 2008, 36, 129-139. [CrossRef]

29. Ferenczi, E.; Deisseroth, K. When the electricity (and the lights) go out: Transient changes in excitability. Nat. Neurosci. 2012, 15, 1058-1060. [CrossRef]

30. Chow, B.Y.; Han, X.; Dobry, A.S.; Qian, X.; Chuong, A.S.; Li, M.; Henninger, M.A.; Belfort, G.M.; Lin, Y.; Monahan, P.E.; et al. High-performance genetically targetable optical neural silencing by light-driven proton pumps. Nature 2010, 463, 98-102. [CrossRef]

31. Marshel, J.H.; Kim, Y.S.; Machado, T.A.; Quirin, S.; Benson, B.; Kadmon, J.; Raja, C.; Chibukhchyan, A.; Ramakrishnan, C.; Inoue, M.; et al. Cortical layer-specific critical dynamics triggering perception. Science 2019, 365, eaaw5202. [CrossRef]

32. Berndt, A.; Lee, S.Y.; Ramakrishnan, C.; Deisseroth, K. Structure-Guided Transformation of Channelrhodopsin into a LightActivated Chloride Channel. Science 2014, 344, 420-424. [CrossRef]

33. Gong, X.; Mendoza-Halliday, D.; Ting, J.T.; Kaiser, T.; Sun, X.Y.; Bastos, A.M.; Wimmer, R.D.; Guo, B.L.; Chen, Q.; Zhou, Y.; et al. An Ultra-Sensitive Step-Function Opsin for Minimally Invasive Optogenetic Stimulation in Mice and Macaques. Neuron 2020, 107, 38-51.e8. [CrossRef]

34. Zabelskii, D.; Alekseev, A.; Kovalev, K.; Rankovic, V.; Balandin, T.; Soloviov, D.; Bratanov, D.; Savelyeva, E.; Podolyak, E.; Volkov, D.; et al. Viral rhodopsins 1 are an unique family of light-gated cation channels. Nat. Commun. 2020, 11, 5707. [CrossRef]

35. Ganjawala, T.H.; Lu, Q.; Fenner, M.D.; Abrams, G.W.; Pan, Z.H. Improved CoChR Variants Restore Visual Acuity and Contrast Sensitivity in a Mouse Model of Blindness under Ambient Light Conditions. Mol. Ther. 2019, 27, 1195-1205. [CrossRef]

36. Stujenske, J.M.; Spellman, T.; Gordon, J.A. Modeling the Spatiotemporal Dynamics of Light and Heat Propagation for In Vivo Optogenetics. Cell Rep. 2015, 12, 525-534. [CrossRef] 
37. Vierock, J.; Rodriguez-Rozada, S.; Dieter, A.; Pieper, F.; Sims, R.; Tenedini, F.; Bergs, A.C.F.; Bendifallah, I.; Zhou, F.M.; Zeitzschel, N.; et al. BiPOLES is an optogenetic tool developed for bidirectional dual-color control of neurons. Nat. Commun. 2021, $12,4527$. [CrossRef]

38. Taslimi, A.; Zoltowski, B.; Miranda, J.G.; Pathak, G.P.; Hughes, R.M.; Tucker, C.L. Optimized second-generation CRY2-CIB dimerizers and photoactivatable Cre recombinase. Nat. Chem. Biol. 2016, 12, 425-430. [CrossRef]

39. Zhang, W.; Lohman, A.W.; Zhuravlova, Y.; Lu, X.C.; Wiens, M.D.; Hoi, H.; Yaganoglu, S.; Mohr, M.A.; Kitova, E.N.; Klassen, J.S.; et al. Optogenetic control with a photocleavable protein, PhoCl. Nat. Methods 2017, 14, 391-394. [CrossRef]

40. Zayner, J.P.; Sosnick, T.R. Factors That Control the Chemistry of the LOV Domain Photocycle. PLoS ONE 2014, 9, e87074. [CrossRef]

41. Berglund, K.; Clissold, K.; Li, H.F.E.; Wen, L.; Park, S.Y.; Gleixner, J.; Klein, M.E.; Lu, D.Y.; Barter, J.W.; Rossi, M.A.; et al. Luminopsins integrate opto- and chemogenetics by using physical and biological light sources for opsin activation. Proc. Natl. Acad. Sci. USA 2016, 113, E358-E367. [CrossRef] [PubMed]

42. English, A.W.; Berglund, K.; Carrasco, D.; Goebel, K.; Gross, R.E.; Isaacson, R.; Mistretta, O.C.; Wynans, C. Bioluminescent Optogenetics: A Novel Experimental Therapy to Promote Axon Regeneration after Peripheral Nerve Injury. Int. J. Mol. Sci. 2021, 22, 7217. [CrossRef] [PubMed]

43. Yoon, H.H.; Park, J.H.; Kim, Y.H.; Min, J.; Hwang, E.; Lee, C.J.; Suh, J.K.; Hwang, O.; Jeon, S.R. Optogenetic inactivation of the subthalamic nucleus improves forelimb akinesia in a rat model of Parkinson disease. Neurosurgery 2014, 74, 533-541. [CrossRef] [PubMed]

44. Pisanello, M.; Pisano, F.; Sileo, L.; Maglie, E.; Bellistri, E.; Spagnolo, B.; Mandelbaum, G.; Sabatini, B.L.; De Vittorio, M.; Pisanello, F. Tailoring light delivery for optogenetics by modal demultiplexing in tapered optical fibers. Sci. Rep. 2018, 8, 4467. [CrossRef]

45. Ji, B.W.; Guo, Z.J.; Wang, M.H.; Yang, B.; Wang, X.L.; Li, W.; Liu, J.Q. Flexible polyimide-based hybrid optoelectric neural interface with 16 channels of micro-LEDs and electrodes. Microsyst. Nanoeng. 2018, 4, 27. [CrossRef]

46. Baffou, G.; Quidant, R. Thermo-plasmonics: Using metallic nanostructures as nano-sources of heat. Laser Photonics Rev. 2013, 7, 171-187. [CrossRef]

47. Zhang, J.; Liu, X.; Xu, W.; Luo, W.; Li, M.; Chu, F.; Xu, L.; Cao, A.; Guan, J.; Tang, S.; et al. Stretchable Transparent Electrode Arrays for Simultaneous Electrical and Optical Interrogation of Neural Circuits in Vivo. Nano Lett. 2018, 18, 2903-2911. [CrossRef]

48. Bansal, A.; Liu, H.C.; Jayakumar, M.K.G.; Andersson-Engels, S.; Zhang, Y. Quasi-Continuous Wave Near-Infrared Excitation of Upconversion Nanoparticles for Optogenetic Manipulation of C-elegans. Small 2016, 12, 1732-1743. [CrossRef]

49. Ai, X.; Lyu, L.; Zhang, Y.; Tang, Y.; Mu, J.; Liu, F.; Zhou, Y.; Zuo, Z.; Liu, G.; Xing, B. Remote Regulation of Membrane Channel Activity by Site-Specific Localization of Lanthanide-Doped Upconversion Nanocrystals. Angew. Chem. Int. Ed. 2017, 56, 3031-3035. [CrossRef]

50. Chen, S.; Weitemier, A.Z.; Zeng, X.; He, L.; Wang, X.; Tao, Y.; Huang, A.J.Y.; Hashimotodani, Y.; Kano, M.; Iwasaki, H.; et al. Near-infrared deep brain stimulation via upconversion nanoparticle-mediated optogenetics. Science 2018, 359, 679-684. [CrossRef]

51. Krukowski, K.; Nolan, A.; Becker, M.; Picard, K.; Vernoux, N.; Frias, E.S.; Feng, X.; Tremblay, M.E.; Rosi, S. Novel microgliamediated mechanisms underlying synaptic loss and cognitive impairment after traumatic brain injury. Brain Behav. Immun. 2021, 98, 122-135. [CrossRef] [PubMed]

52. Nguyen, T.; Al-Juboori, M.H.; Walerstein, J.; Xiong, W.; Jin, X. Impaired Glutamate Receptor Function Underlies Early Activity Loss of Ipsilesional Motor Cortex after Closed-Head Mild Traumatic Brain Injury. J. Neurotrauma 2021, 38, 2018-2029. [CrossRef] [PubMed]

53. Zeng, X.J.; Li, P.; Ning, Y.L.; Zhao, Y.; Peng, Y.; Yang, N.; Xu, Y.W.; Chen, J.F.; Zhou, Y.G. A(2A)R inhibition in alleviating spatial recognition memory impairment after TBI is associated with improvement in autophagic flux in RSC. J. Cell. Mol. Med. 2020, 24, 7000-7014. [CrossRef] [PubMed]

54. Mester, J.R.; Bazzigaluppi, P.; Dorr, A.; Beckett, T.; Burke, M.; McLaurin, J.; Sled, J.G.; Stefanovic, B. Attenuation of tonic inhibition prevents chronic neurovascular impairments in a Thy1-ChR2 mouse model of repeated, mild traumatic brain injury. Theranostics 2021, 11, 7685-7699. [CrossRef] [PubMed]

55. Adams, C.; Bazzigaluppi, P.; Beckett, T.L.; Bishay, J.; Weisspapir, I.; Dorr, A.; Mester, J.R.; Steinman, J.; Hirschler, L.; Warnking, J.M.; et al. Neurogliovascular dysfunction in a model of repeated traumatic brain injury. Theranostics 2018, 8 , 4824-4836. [CrossRef]

56. Ndode-Ekane, X.E.; Puigferrat Pérez, M.D.M.; Di Sapia, R.; Lapinlampi, N.; Pitkänen, A. Reorganization of Thalamic Inputs to Lesioned Cortex Following Experimental Traumatic Brain Injury. Int. J. Mol. Sci. 2021, 22, 6329. [CrossRef]

57. Zhao, M.L.; Chen, S.J.; Li, X.H.; Wang, L.N.; Chen, F.; Zhong, S.J.; Yang, C.; Sun, S.K.; Li, J.J.; Dong, H.J.; et al. Optical Depolarization of DCX-Expressing Cells Promoted Cognitive Recovery and Maturation of Newborn Neurons via the Wnt/betaCatenin Pathway. J. Alzheimers Dis. 2018, 63, 303-318. [CrossRef]

58. Singla, S.; Garcia, G.E.; Rovenolt, G.E.; Soto, A.L.; Gilmore, E.J.; Hirsch, L.J.; Blumenfeld, H.; Sheth, K.N.; Omay, S.B.; Struck, A.F.; et al. Detecting Seizures and Epileptiform Abnormalities in Acute Brain Injury. Curr. Neurol. Neurosci. Rep. 2020, $20,42$. [CrossRef]

59. Haque, A.; Ray, S.K.; Cox, A.; Banik, N.L. Neuron specific enolase: A promising therapeutic target in acute spinal cord injury. Metab. Brain Dis. 2016, 31, 487-495. [CrossRef] 
60. Carney, N.; Totten, A.M.; O’Reilly, C.; Ullman, J.S.; Hawryluk, G.W.; Bell, M.J.; Bratton, S.L.; Chesnut, R.; Harris, O.A.; Kissoon, N.; et al. Guidelines for the Management of Severe Traumatic Brain Injury, Fourth Edition. Neurosurgery 2017, 80, 6-15. [CrossRef]

61. Bouzat, P.; Marques-Vidal, P.; Zerlauth, J.B.; Sala, N.; Suys, T.; Schoettker, P.; Bloch, J.; Daniel, R.T.; Levivier, M.; Meuli, R.; et al. Accuracy of brain multimodal monitoring to detect cerebral hypoperfusion after traumatic brain injury*. Crit. Care Med. 2015, 43, 445-452. [CrossRef] [PubMed]

62. Aries, M.J.; Czosnyka, M.; Budohoski, K.P.; Steiner, L.A.; Lavinio, A.; Kolias, A.G.; Hutchinson, P.J.; Brady, K.M.; Menon, D.K.; Pickard, J.D.; et al. Continuous determination of optimal cerebral perfusion pressure in traumatic brain injury. Crit. Care Med. 2012, 40, 2456-2463. [CrossRef] [PubMed]

63. Gong, Y.; Huang, C.; Li, J.Z.; Grewe, B.F.; Zhang, Y.; Eismann, S.; Schnitzer, M.J. High-speed recording of neural spikes in awake mice and flies with a fluorescent voltage sensor. Science 2015, 350, 1361-1366. [CrossRef] [PubMed]

64. Cao, G.; Platisa, J.; Pieribone, V.A.; Raccuglia, D.; Kunst, M.; Nitabach, M.N. Genetically Targeted Optical Electrophysiology in Intact Neural Circuits. Cell 2013, 154, 904-913. [CrossRef]

65. Jones, S.; Schwartzbauer, G.; Jia, X.F. Brain Monitoring in Critically Neurologically Impaired Patients. Int. J. Mol. Sci. 2017, 18, 43. [CrossRef]

66. Jayaprakash, N.; Wang, Z.; Hoeynck, B.; Krueger, N.; Kramer, A.; Balle, E.; Wheeler, D.S.; Wheeler, R.A.; Blackmore, M.G. Optogenetic Interrogation of Functional Synapse Formation by Corticospinal Tract Axons in the Injured Spinal Cord. J. Neurosci. 2016, 36, 5877-5890. [CrossRef]

67. Butler, C.R.; Boychuk, J.A.; Pomerleau, F.; Alcala, R.; Huettl, P.; Ai, Y.; Jakobsson, J.; Whiteheart, S.W.; Gerhardt, G.A.; Smith, B.N.; et al. Modulation of epileptogenesis: A paradigm for the integration of enzyme-based microelectrode arrays and optogenetics. Epilepsy Res. 2020, 159, 106244. [CrossRef]

68. Roy, D.S.; Arons, A.; Mitchell, T.I.; Pignatelli, M.; Ryan, T.J.; Tonegawa, S. Memory retrieval by activating engram cells in mouse models of early Alzheimer's disease. Nature 2016, 531, 508-512. [CrossRef]

69. Howe, M.W.; Dombeck, D.A. Rapid signalling in distinct dopaminergic axons during locomotion and reward. Nature 2016, 535, 505-510. [CrossRef]

70. Gritton, H.J.; Howe, W.M.; Romano, M.F.; DiFeliceantonio, A.G.; Kramer, M.A.; Saligrama, V.; Bucklin, M.E.; Zemel, D.; Han, $\mathrm{X}$. Unique contributions of parvalbumin and cholinergic interneurons in organizing striatal networks during movement. Nat. Neurosci. 2019, 22, 586-597. [CrossRef]

71. Cheng, M.Y.; Wang, E.H.; Woodson, W.J.; Wang, S.; Sun, G.H.; Lee, A.G.; Arac, A.; Fenno, L.E.; Deisseroth, K.; Steinberg, G.K. Optogenetic neuronal stimulation promotes functional recovery after stroke. Proc. Natl. Acad. Sci. USA 2014, 111, 12913-12918. [CrossRef]

72. Shah, A.M.; Ishizaka, S.; Cheng, M.Y.; Wang, E.H.; Bautista, A.R.; Levy, S.; Smerin, D.; Sun, G.; Steinberg, G.K. Optogenetic neuronal stimulation of the lateral cerebellar nucleus promotes persistent functional recovery after stroke. Sci. Rep. 2017, 7, 46612 [CrossRef]

73. Pendharkar, A.V.; Smerin, D.; Gonzalez, L.; Wang, E.H.; Levy, S.; Wang, S.; Ishizaka, S.; Ito, M.; Uchino, H.; Chiang, T.; et al. Optogenetic Stimulation Reduces Neuronal Nitric Oxide Synthase Expression After Stroke. Transl. Stroke Res. 2021, 12, 347-356. [CrossRef]

74. Dias, D.O.; Kim, H.; Holl, D.; Werne Solnestam, B.; Lundeberg, J.; Carlén, M.; Göritz, C.; Frisén, J. Reducing Pericyte-Derived Scarring Promotes Recovery after Spinal Cord Injury. Cell 2018, 173, 153-165.e22. [CrossRef]

75. Tennant, K.A.; Taylor, S.L.; White, E.R.; Brown, C.E. Optogenetic rewiring of thalamocortical circuits to restore function in the stroke injured brain. Nat. Commun. 2017, 8, 15879. [CrossRef]

76. Conti, E.; Mascaro, A.L.A.; Scaglione, A.; de Vito, G.; Calugi, F.; Pasquini, M.; Pizzorusso, T.; Micera, S.; Pavone, F.S. Restoration of motor-evoked cortical activity is a distinguishing feature of the most effective rehabilitation therapy after stroke. bioRxiv 2021 Available online: https:/ / www.biorxiv.org/content/10.1101/2020.03.05.974972v3.full (accessed on 18 October 2021).

77. Akamatsu, Y.; Hanafy, K.A. Cell Death and Recovery in Traumatic Brain Injury. Neurotherapeutics 2020, 17, 446-456. [CrossRef]

78. Luo, C.L.; Li, B.X.; Li, Q.Q.; Chen, X.P.; Sun, Y.X.; Bao, H.J.; Dai, D.K.; Shen, Y.W.; Xu, H.F.; Ni, H.; et al. Autophagy Is Involved in Traumatic Brain Injury-Induced Cell Death and Contributes to Functional Outcome Deficits in Mice. Neuroscience 2011, 184, 54-63. [CrossRef]

79. Marmarou, A. Intracellular acidosis in human and experimental brain injury. J. Neurotrauma 1992, 9 (Suppl. 2), S551-S562.

80. Bo, B.; Li, Y.; Li, W.L.; Wang, Y.T.; Tong, S.B. Optogenetic translocation of protons out of penumbral neurons is protective in a rodent model of focal cerebral ischemia. Brain Stimul. 2020, 13, 881-890. [CrossRef]

81. Pires Monteiro, S.; Voogd, E.; Muzzi, L.; De Vecchis, G.; Mossink, B.; Levers, M.; Hassink, G.; Van Putten, M.; Le Feber, J.; Hofmeijer, J.; et al. Neuroprotective effect of hypoxic preconditioning and neuronal activation in a in vitro human model of the ischemic penumbra. J. Neural Eng. 2021, 18, 036016. [CrossRef]

82. Lanshakov, D.A.; Drozd, U.S.; Dygalo, N.N. Optogenetic Stimulation Increases Level of Antiapoptotic Protein Bcl-xL in Neurons. Biochemistry 2017, 82, 340-344. [CrossRef]

83. Beppu, K.; Sasaki, T.; Tanaka, K.F.; Yamanaka, A.; Fukazawa, Y.; Shigemoto, R.; Matsui, K. Optogenetic countering of glial acidosis suppresses glial glutamate release and ischemic brain damage. Neuron 2014, 81, 314-320. [CrossRef] 
84. De Feo, D.; Merlini, A.; Laterza, C.; Martino, G. Neural stem cell transplantation in central nervous system disorders: From cell replacement to neuroprotection. Curr. Opin. Neurol. 2012, 25, 322-333. [CrossRef]

85. Giusto, E.; Donegà, M.; Cossetti, C.; Pluchino, S. Neuro-immune interactions of neural stem cell transplants: From animal disease models to human trials. Exp. Neurol. 2014, 260, 19-32. [CrossRef]

86. Ceto, S.; Sekiguchi, K.J.; Takashima, Y.; Nimmerjahn, A.; Tuszynski, M.H. Neural Stem Cell Grafts Form Extensive Synaptic Networks that Integrate with Host Circuits after Spinal Cord Injury. Cell Stem Cell 2020, 27, 430-440.e5. [CrossRef]

87. Yu, S.P.; Tung, J.K.; Wei, Z.Z.; Chen, D.; Berglund, K.; Zhong, W.; Zhang, J.Y.; Gu, X.; Song, M.; Gross, R.E.; et al. Optochemogenetic Stimulation of Transplanted iPS-NPCs Enhances Neuronal Repair and Functional Recovery after Ischemic Stroke. J. Neurosci. 2019, 39, 6571-6594. [CrossRef]

88. Wahl, A.S.; Büchler, U.; Brändli, A.; Brattoli, B.; Musall, S.; Kasper, H.; Ineichen, B.V.; Helmchen, F.; Ommer, B.; Schwab, M.E. Optogenetically stimulating intact rat corticospinal tract post-stroke restores motor control through regionalized functional circuit formation. Nat. Commun. 2017, 8, 1187. [CrossRef]

89. Daadi, M.M.; Klausner, J.Q.; Bajar, B.; Goshen, I.; Lee-Messer, C.; Lee, S.Y.; Winge, M.C.; Ramakrishnan, C.; Lo, M.; Sun, G.; et al. Optogenetic Stimulation of Neural Grafts Enhances Neurotransmission and Downregulates the Inflammatory Response in Experimental Stroke Model. Cell Transplant. 2016, 25, 1371-1380. [CrossRef]

90. Giraldo, E.; Palmero-Canton, D.; Martinez-Rojas, B.; Sánchez-Martín, M.D.; Moreno-Manzano, V. Optogenetic Modulation of Neural Progenitor Cells Improves Neuroregenerative Potential. Int. J. Mol. Sci. 2021, 22, 365. [CrossRef]

91. Lu, Y.; Jiang, L.; Li, W.; Qu, M.; Song, Y.; He, X.; Zhang, Z.; Yang, G.Y.; Wang, Y. Optogenetic Inhibition of Striatal Neuronal Activity Improves the Survival of Transplanted Neural Stem Cells and Neurological Outcomes after Ischemic Stroke in Mice. Stem Cells Int. 2017, 2017, 4364302. [CrossRef]

92. Tseng, T.C.; Tao, L.; Hsieh, F.Y.; Wei, Y.; Chiu, I.M.; Hsu, S.H. An Injectable, Self-Healing Hydrogel to Repair the Central Nervous System. Adv. Mater. 2015, 27, 3518-3524. [CrossRef] [PubMed]

93. Hsieh, F.Y.; Lin, H.H.; Hsu, S.H. 3D bioprinting of neural stem cell-laden thermoresponsive biodegradable polyurethane hydrogel and potential in central nervous system repair. Biomaterials 2015, 71, 48-57. [CrossRef] [PubMed]

94. Hsieh, F.Y.; Han, H.W.; Chen, X.R.; Yang, C.S.; Wei, Y.; Hsu, S.H. Non-viral delivery of an optogenetic tool into cells with self-healing hydrogel. Biomaterials 2018, 174, 31-40. [CrossRef] [PubMed]

95. Sahel, J.A.; Boulanger-Scemama, E.; Pagot, C.; Arleo, A.; Galluppi, F.; Martel, J.N.; Esposti, S.D.; Delaux, A.; Aubert, J.B.D.; de Montleau, C.; et al. Partial recovery of visual function in a blind patient after optogenetic therapy. Nat. Med. 2021, 27, 1223-1229. [CrossRef]

96. Alilain, W.J.; Li, X.; Horn, K.P.; Dhingra, R.; Dick, T.E.; Herlitze, S.; Silver, J. Light-induced rescue of breathing after spinal cord injury. J. Neurosci. 2008, 28, 11862-11870. [CrossRef]

97. Yohn, D.C.; Miles, G.B.; Rafuse, V.F.; Brownstone, R.M. Transplanted mouse embryonic stem-cell-derived motoneurons form functional motor units and reduce muscle atrophy. J. Neurosci. 2008, 28, 12409-12418. [CrossRef]

98. Awad, B.I.; Gutierrez, D.V.; Alilain, W.; Steinmetz, M.P. Optogenetic Photostimulation to Control Bladder Function After Experimental Spinal Cord Injury. Spine J. 2013, 13, S12. [CrossRef]

99. Gutruf, P.; Rogers, J.A. Implantable, wireless device platforms for neuroscience research. Curr. Opin. Neurobiol. 2018, 50, 42-49. [CrossRef]

100. Donadon, I.; Bussani, E.; Riccardi, F.; Licastro, D.; Romano, G.; Pianigiani, G.; Pinotti, M.; Konstantinova, P.; Evers, M.; Lin, S.; et al. Rescue of spinal muscular atrophy mouse models with AAV9-Exon-specific U1 snRNA. Nucleic Acids Res. 2019, 47, 7618-7632. [CrossRef]

101. Gardner, M.R.; Fellinger, C.H.; Kattenhorn, L.M.; Davis-Gardner, M.E.; Weber, J.A.; Alfant, B.; Zhou, A.S.; Prasad, N.R.; Kondur, H.R.; Newton, W.A.; et al. AAV-delivered eCD4-Ig protects rhesus macaques from high-dose SIVmac239 challenges. Sci. Transl. Med. 2019, 11, eaau5409. [CrossRef]

102. Leng, Y.; Li, P.; Zhou, L.; Xiao, L.; Liu, Y.; Zheng, Z.; Qin, F.; Hao, Q.; Xu, H.; Yao, S.; et al. Long-Term Correction of Copper Metabolism in Wilson's Disease Mice with AAV8 Vector Delivering Truncated ATP7B. Hum. Gene Ther. 2019, 30, 1494-1504. [CrossRef]

103. Kaiser, J. Virus used in gene therapies may pose cancer risk, dog study hints. Science 2020, 10. [CrossRef]

104. Galvan, A.; Stauffer, W.R.; Acker, L.; El-Shamayleh, Y.; Inoue, K.I.; Ohayon, S.; Schmid, M.C. Nonhuman Primate Optogenetics: Recent Advances and Future Directions. J. Neurosci. 2017, 37, 10894-10903. [CrossRef]

105. Maimon, B.E.; Diaz, M.; Revol, E.C.M.; Schneider, A.M.; Leaker, B.; Varela, C.E.; Srinivasan, S.; Weber, M.B.; Herr, H.M. Optogenetic Peripheral Nerve Immunogenicity. Sci. Rep. 2018, 8, 14076. [CrossRef]

106. Adamczyk, A.K.; Zawadzki, P. The Memory-Modifying Potential of Optogenetics and the Need for Neuroethics. NanoEthics 2020, 14, 207-225. [CrossRef] 